\title{
Pharmacognostical \& physicochemical Analysis of Musta-Triphaladi Avalehya, used in the management of Thalassemia Major
}

\author{
Review Article
}

\author{
Kalawana OTMRKSB ${ }^{1 *}$, Harisha $\mathrm{CR}^{2}$, Rajagopala $\mathrm{S}^{3}$, Patel $\mathrm{KS}^{4}$, Kori $\mathrm{VK}^{3}$
}

\author{
1. PG Scholar, 3. Assistant Professor, 4. Professor and Head, Department of Kaumarbhritya \\ 2. Head, Pharmacognosy Laboratory \\ I.P.G.T.\&R.A., Gujarat Ayurved University, Jamnagar, Gujarat, India.361008
}

\begin{abstract}
According to the World Health Organization (WHO) Thalassemia is the most prevalent genetic blood disorder in the world. Thalassemic patients are suffering from hypochromic, microcytic anemia due to the early excessive destruction of red blood cells. Due to the complications and incompleteness of modern medical management of the disease, need arises of some adjuvant therapy like Ayurveda. Hence present study was carried out to standardize the finished product of Musta-triphaladi Avaleha, an Ayurveda formulation which is used in the management of Thalassemia Major, to conform its identity, quality and purity. The finished product was used for the pharmacognostical study; organoleptic characteristics and microscopical study of the Musta-triphaladi Avaleha by showing characteristic features of hat all ingredients used were genuine and all were found in the finished product too. Physico-Chemical Parameters of Musta-Triphaladi Avaleha were found as $\mathrm{pH}$ value 6.0, ash value $0.142 \mathrm{~g}$ and Acid insoluble ash was $0.193 \% \mathrm{w} / \mathrm{w}$.
\end{abstract}

Keywords: Musta-triphaladi Avaleha, Pharmacognostical, Physico-Chemical, Thalassemia Major.

\section{Introduction}

In the present scientific era, Ayurveda also becomes globalized due to its holistic nature leading to high demand. There is a huge trend in people to turn towards herbal medicine like Ayurveda. Though Ayurveda is holistic and cost effective with good therapeutic effects, the therapeutic effect depends on the quality of the drug administered. A quality drug results into best results. Hence present study was carried out to standardize a finished product viz. MustaTriphaladi Avaleha, to conform its identity, quality, and purity. This is an ayurvedic formulation modified by Rajgolkar S. etal (2014) (1) which is used as an adjuvant drug in the management of Thalassemia Major.

According to the World Health Organization (WHO) thalassemias are the most common inherited single-gene disorders in the world (2). Thalassemia is a monogenic disorder characterized by abnormal synthesis of hemoglobin due to defects in the globin chain. This causes early excessive destruction of red blood cells leading to hypochromic, microcytic anemia the characteristic presenting symptom of thalassemia.

*Corresponding Author:

Kalawana OTMRKSB

PG scholar, Department of Kaumarbhritya,

IPGT\&RA, Gujarat Ayurved University, Jamnagar -361008.

E-mail: dr.senanikalawana@gmail.com
According to clinical severity, thalassemia can be classified into 3 types, such as Thalassemia Major (TM), Thalassemia Intermedia (TI) and Thalassemia minor (Tm) or traits (3). The mainstay of managing the condition is repeated blood transfusion and it is the only and easy measure that each thalassemic patient can undergo. But due to the repeated blood transfusion therapy, and increased gastrointestinal iron absorption, iron gets accumulated in the body. This Iron overload causes morbidity and organ toxicity (4) and this accumulated Iron is reduced by regular chelation therapy, though it is also having some side effects (5). Due to those complications and incompleteness of modern medical management, there is a need of some adjuvant therapy (like Ayurveda), and it should be applied simultaneously with the blood transfusion which help to increase the blood transfusion interval, to enhance the quality of life and life span of the thalassemic patients, and to minimize the complications. Musta-triphaladi Avaleha is a herbal drug compound prepared in dosage format of Avaleha (i.e. lincture) and has been tried clinically as an adjuvant with proven results. To ensure the quality standards of the formulation such as identity, quality, and purity of ingredients and finished product along with preliminary physico-chemical parameters and pharmacognostical characteristics, this study was carried out.

\section{Materials and methods: \\ Ingredients of Musta-Triphaladi avalehya}

Ingredients of Musta-Triphaladi Avaleha are as shown in the Table - 1 . 
Table 1. Ingredients of Musta-Triphaladi Avaleha

\begin{tabular}{|c|c|c|c|}
\hline No. & Drug Name & Latin Name & Part Used \\
\hline 1 & Musta & Cyprus rotundus Nust. & Dry Rhizome \\
\hline 2 & Amalaki & Emblica officinalis Gaertn. & Dry Fruit \\
\hline 3 & Haritaki & Terminalia chebula Retz. & Dry Fruit \\
\hline 4 & Vibhitaki & Terminalia bellerica Roxb. & Dry Fruit \\
\hline 5 & Katuki & Picrorhiza kurroa Royle ex Benth. & Dry Root \\
\hline 6 & Kakmachi & Solanum nigrum Linn. & Dry Whole plant \\
\hline 7 & Kutaja & Holarrhena antidysenterica Wall. & Dry Bark \\
\hline 8 & Haridra & Curcuma longa Linn. & Dry Rhizome \\
\hline 9 & Vidanga & Embelia robusta Burm & Dry Fruit \\
\hline 10 & Guduchi & Tinospora cordifolia Willd. & Dry Stem \\
\hline 11 & Shweta Punarnava & Trianthema portulacastrum Linn. & Dry Root \\
\hline 12 & Sharapunkha & Tephrosia purpurea Linn. & Dry Root \\
\hline 13 & Apamarga & Achyranthus aspera Linn. & Dry Whole plant \\
\hline 14 & Kadali & Musa paradisiacal Linn, & Dry Rhizome powder \\
\hline 15 & Shatavari & Aspergus recemosus Willd. & Dry Root \\
\hline 16 & Shigru & Moringa oleifera Lam. & Dry Root bark \\
\hline 17 & Vasa & Adhatoda vasica Nees & Dry Leaves \\
\hline 18 & Daruharidra & Berberis aristata $\mathrm{DC}$ & Dry Root \\
\hline 19 & Sariva & Hemidesmus indicus $\mathrm{R} . \mathrm{Br}$. & Dry Root \\
\hline 20 & Manjishtha & Rubia cordifolia Linn. & Dry Root \\
\hline 21 & Madhu & Honey & $\begin{array}{c}--- \\
\end{array}$ \\
\hline 22 & Sharkara & Saccharum officinarum Linn & Crystal \\
\hline \multirow[t]{5}{*}{23} & Chaturjata & & \\
\hline & Twak & Cinnamomum zeylanicum Blume & Dry Bark \\
\hline & Ela & Elettaria cardamomum Maton & Dry Seed \\
\hline & Tamalapatra & Cinnamomum tamala Nees \& Eberm & Dry Leaf \\
\hline & Nagakesara & Mesua ferrea Linn & Dry Pushpakalika \\
\hline \multirow[t]{4}{*}{24} & Trikatu & & \\
\hline & Shunthi & Zingiber officinale Rosc. & Dry Rhizome \\
\hline & Maricha & Piper nigrum Linn. & Dry Fruit \\
\hline & Pippali & Piper longum Linn. & Dry Fruit \\
\hline
\end{tabular}




\section{Preparation of the drug}

The test drug was prepared in the Pharmacy, Gujarat Ayurved University, Jamnagar. The whole plant of Sharapunkhaa (Tephrosia purpurea Linn.) was purchased from the local market and rhizomes of Kadali (Musa paradisiacal Linn.) were collected from the international hostel premises, GAU, Jamnagar. They were authenticated by the experts of Pharmacognosy laboratory, I. P. G. T. \& R. A., Jamnagar and then submitted in Pharmacy for making of Musta-Triphaladi Avaleha, and the other remaining drugs were provided by the raw drug store of Pharmacy. The Finished product of test drug was used for the pharmacognostical and physico-chemical Parameters study at the Pharmacognosy laboratory and the Pharmaceutical chemistry laboratory respectively.

\section{Pharmacognostical study}

The pharmacognstical study comprises of organoleptic study and microscopic study of finished prouct.

\section{Organoleptic Study:}

Characters like color, odour, taste and touch of Musta-Triphaladi Avaleha are studied by organoleptic paraments i.e. sensory observations.

\section{Microscopic Study:}

Small quantity of Musta-Triphaladi Avaleha was dissolved with distilled water and few drops were spread on a glass slide, covered with a cover slip and excessive water was removed with filter paper. Microscopic evaluation was done with the prepared slide with and without staining studied under Carl-zeiss Trinocular microscope. (6)

\section{Physico-chemical parameters}

Following Physico-chemical parameters were analyzed for different physico-chemical parameters methods at the pharmaceutical chemistry lab, IPGT\& RA. (7)

\section{Physico-chemical Parameters for Musta-Triphaladi Avaleha:}
a. Loss on drying
b. Ash value
c. Water soluble extract
d. Methanol soluble extract
e. $\mathrm{pH}$
f. Acid insoluble Ash

Observations and results:

Pharmacognostical study

Organoleptic study :

Characters like color, odour, taste and touch of Musta-Triphaladi Avaleha were studied by sensory observations results were depicted in the table no2.

Table 2. Organoleptic characteristics of mustatriphaladi avaleha

\begin{tabular}{|l|l|l|}
\hline $\begin{array}{l}\text { Sr. } \\
\text { No. }\end{array}$ & Parameters & Observations \\
\hline 1. & Colour & Chocolate brown \\
\hline 2. & Odour & fragrant \\
\hline 3. & Taste & sweet \\
\hline 4. & Touch & Semi solid \\
\hline
\end{tabular}

Microscopical Study:

Pharmacognostical characterrictics of Mustatriphaladi Avaleha under the microscope showed that Starch grains and Sillica Deposition of Musta, fibers of Amalaki, Scleroids and stones cells of Haritaki, Simple trichome and Epicarp cells of Vibhitaki, Cork cells in surface with brown contents and Parenchyma cells with starch grains of Katuki, Pitted vessels and Pollen grains of Kakamachi, Rhomboidal Crystals and Compound starch Grains of Kutaja, Oleoresins Contents and Parenchyma cells with starch grains of Haridra, Oleoresins and Epicarp cells of Vidanga, Collenchyma cells and Cork cells of Guduchi, Stomata with epidermal cells and Fibers with broad Lumen of Shweta Punarnava, Simple warty trichomes and Spiral vessels of Sharapunkha, Boarded pitted vessels and Septed fibers of Apamarga, simple starch grains and Silica deposition of Kadali, Acicular Crystals and Fragments of scalary form vessels of Shatavari, Fibers passing through medullary region and cork cells in surface view of Shigru, stomata and multi cellular Trichrome of Vasa, Rhomboidal crystals and stone cells of Daruharidra, Prismatic crystals and Stone cells of Sariva, Warty trichome and boarded pitted vessels of Manjishtha, parasite stomata lignified fibers of Twak, Epidermal cells with stomata of Ela, Lignified fibers and Epidermal cells with stomata of Tamalapatra, Pollen grains of Nagakesara, Starch grains and Fragmants of annular vessels of Shunthi, Black debris and stone cells of Maricha, and finally oleoresins contents with stone cells of Pippali; the microphotographs of the same are depicted in Plate1. 
Plate 1. Microphotographs of Musta-triphaladi Avaleha

\begin{tabular}{|c|c|c|}
\hline Starch grains of Musta & Sillica Deposition of Musta & Fibers of Amalaki \\
\hline Scleroids of Haritaki & Stones cells of Haritaki & Simple trichome of Bibitaki \\
\hline Epicarp cells of Bibitaki & $\begin{array}{l}\text { Cork cells in surface with } \\
\text { brown contents of Katuki }\end{array}$ & $\begin{array}{c}\text { Parenchyma cells with starch } \\
\text { grains of Katuki }\end{array}$ \\
\hline Pitted vessels of Kakamachi & Pollen grains of Kakamachi & Rhomboidal Crystals of Kutaja \\
\hline $\begin{array}{l}\text { Compound starch grains of } \\
\text { Kutaja }\end{array}$ & Oleoresins Contents of Haridra & $\begin{array}{l}\text { Parenchyma cells with } \\
\text { starch grains of Haridra }\end{array}$ \\
\hline
\end{tabular}



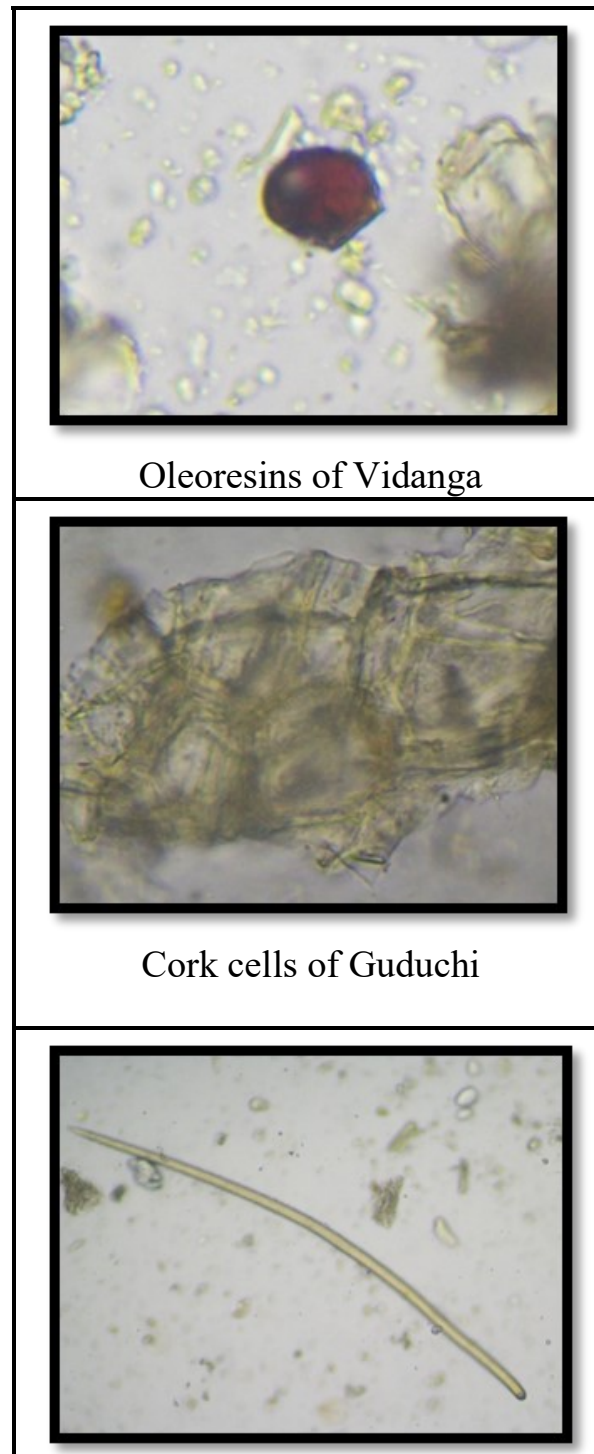

Simple warty trichomes of Sharapunkha

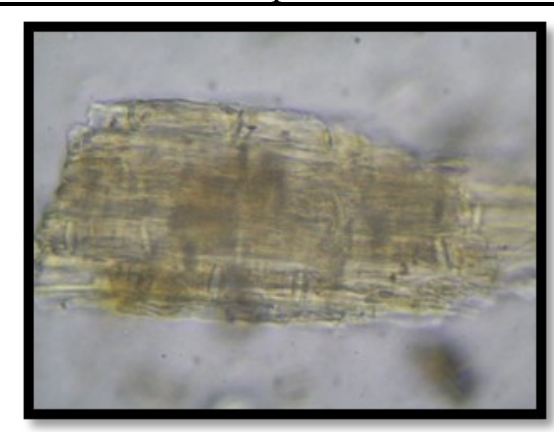

Septed fibers of Apamarga

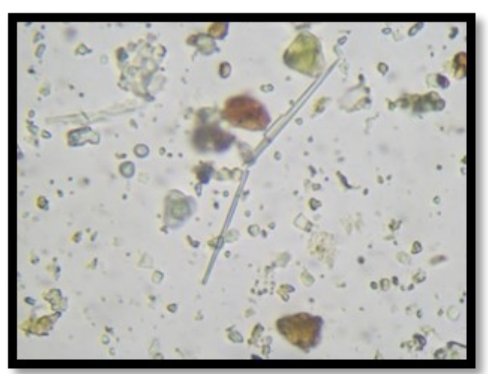

Acicular Crystals of Shatawari

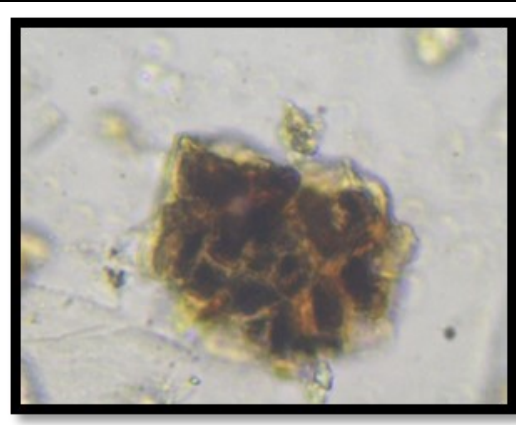

Epicarp cells of Vidanga

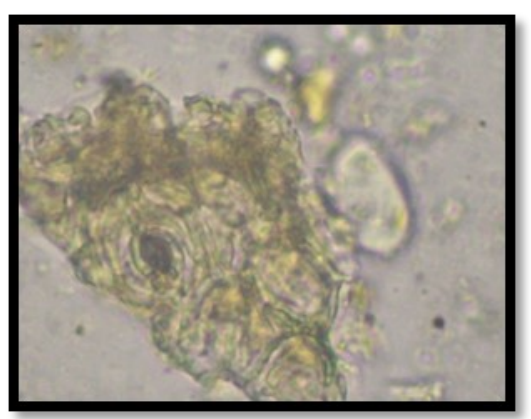

Stomata with epidermal cells of Swetha Punarnawa

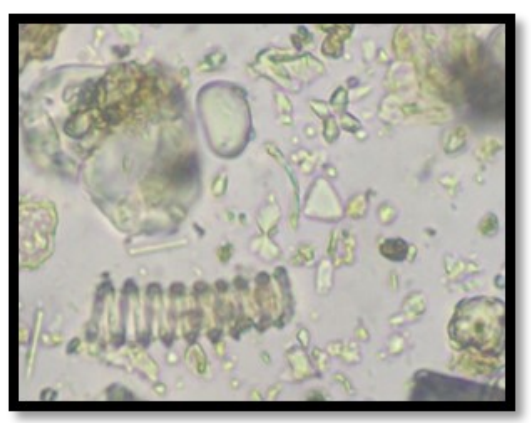

Spiral vessels of Sharapunkha

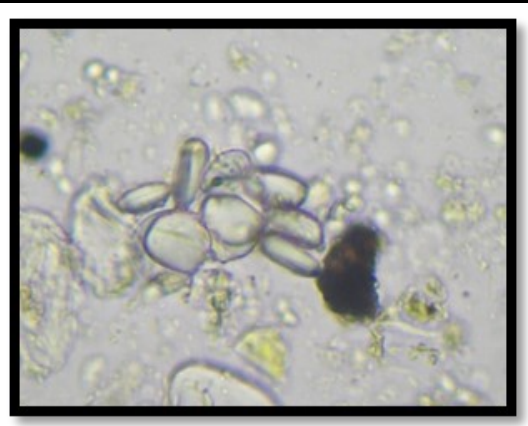

Simple starch grains of Kadali

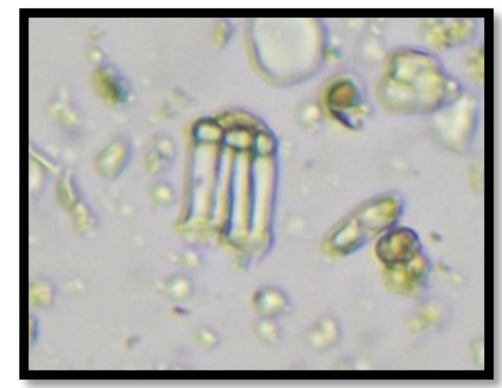

Scalariform vessels of Shatawari

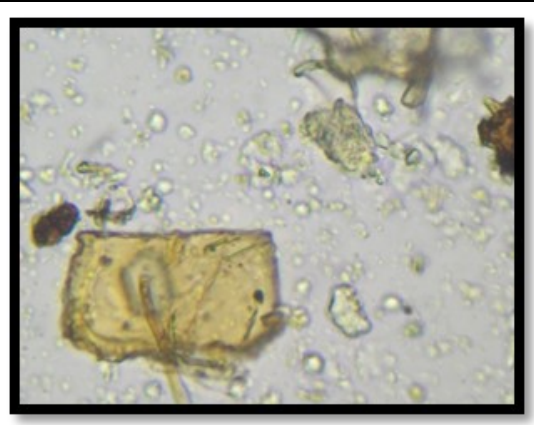

Collenchyma cells of Guduchi

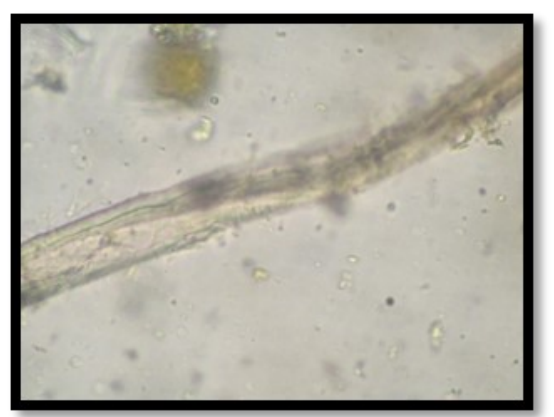

Fibers with broad lumen of Swetha Punarnawa

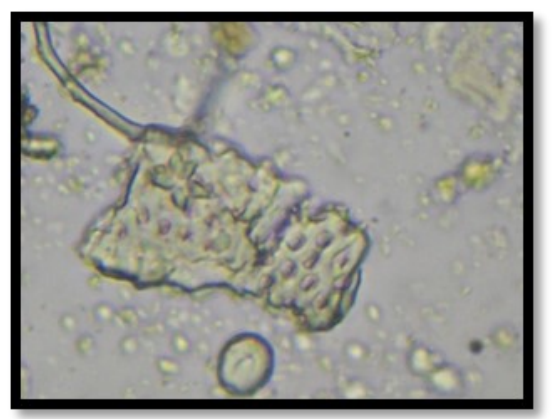

Boarded pitted vessels of Apamarga

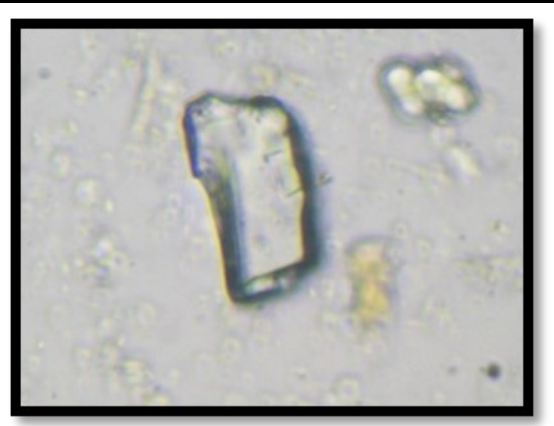

Silica deposition of Kadali

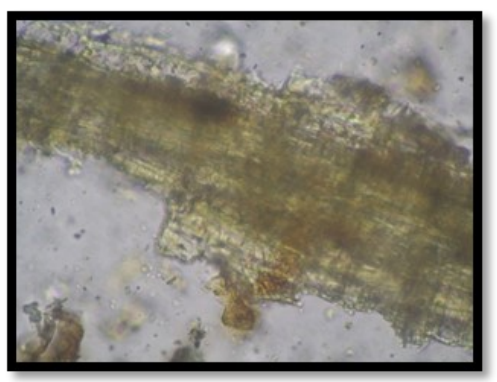

Fibers passing through medullary region of Shigru 


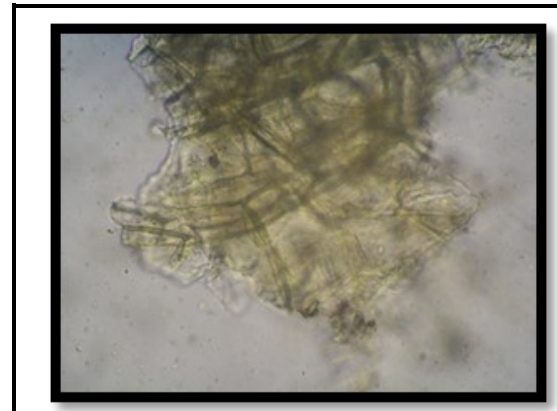

Cork cells in surface view of Shigru

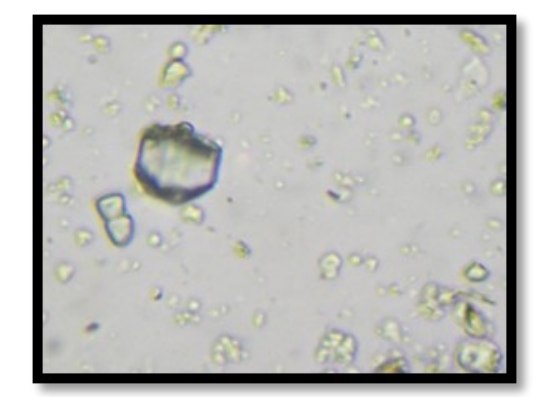

Rhomboidal crystals of Daruharidra

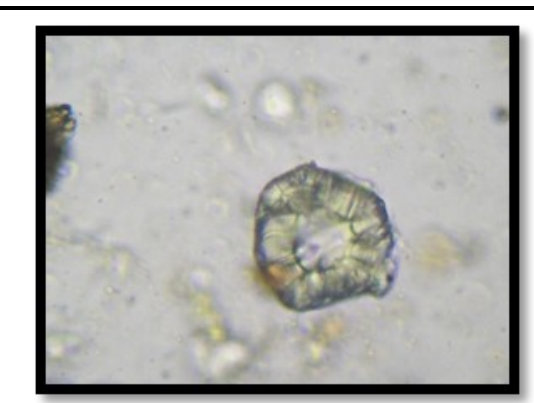

Stone cells of Sariva

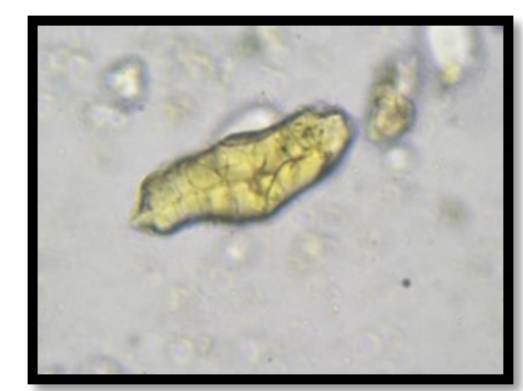

Parasite stomata of Twak

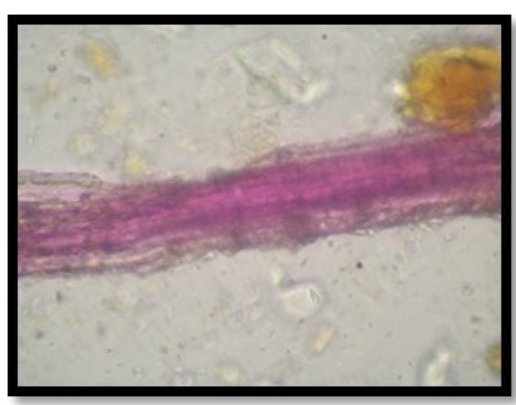

Lignified fibers of Tamalapathra

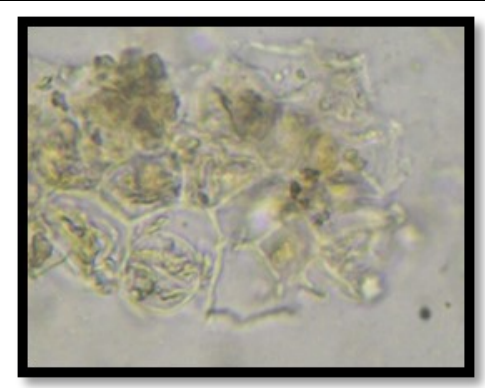

Stomata of Vasa

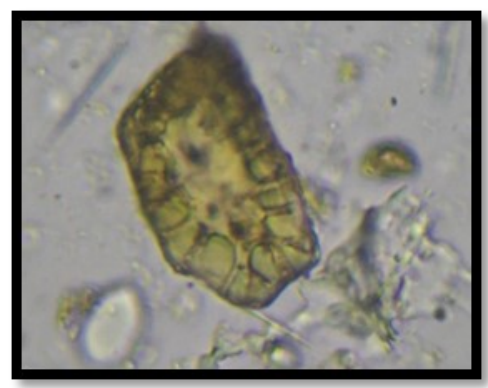

Stone cells of Daruharidra

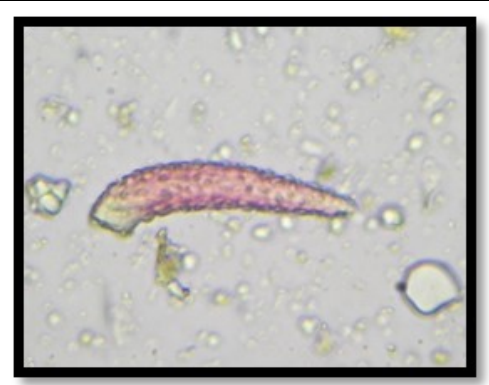

Warty trichome of Manjistha

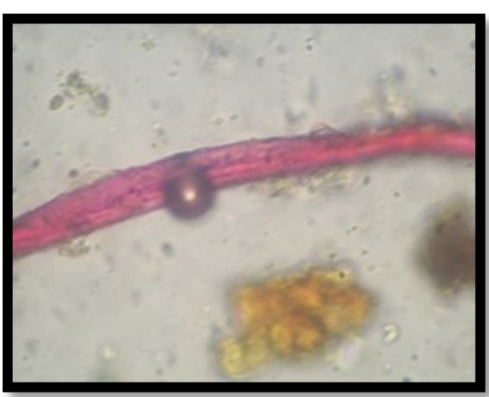

Lignified fibers of Twak

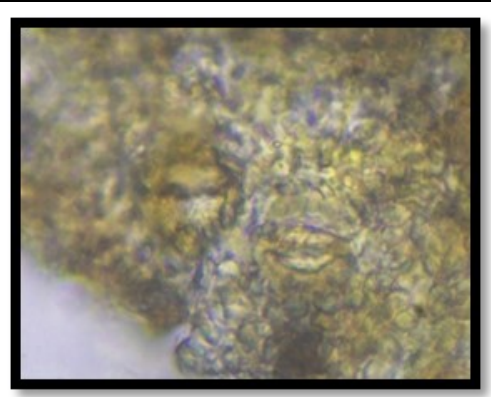

Epidermal cells with stomata of Tamalapathra

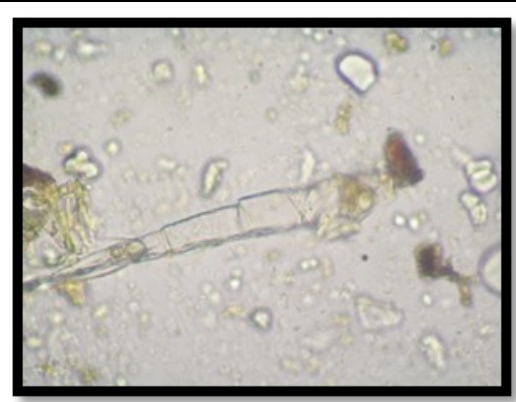

Multi cellular trichrome of Vasa

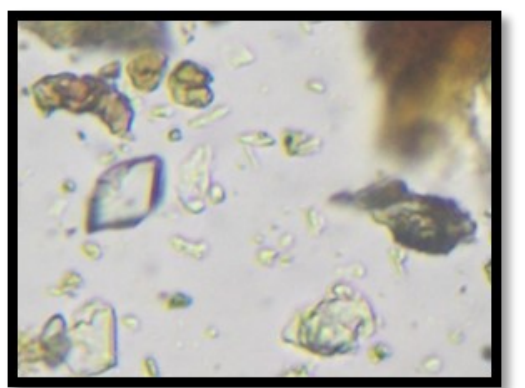

Prismatic crystals of Sariva

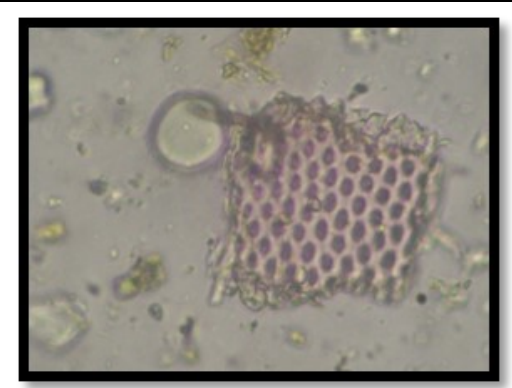

Boarded pitted vessels of Manjistha

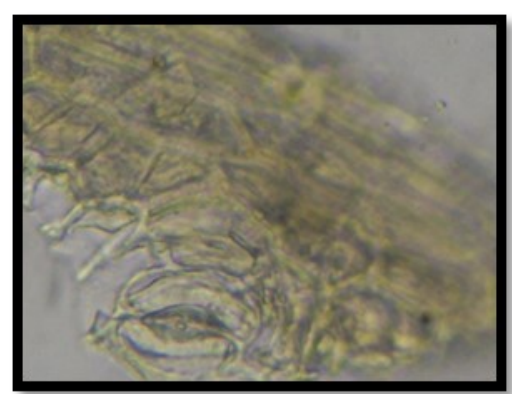

Epidermal cells with stomata of Ela

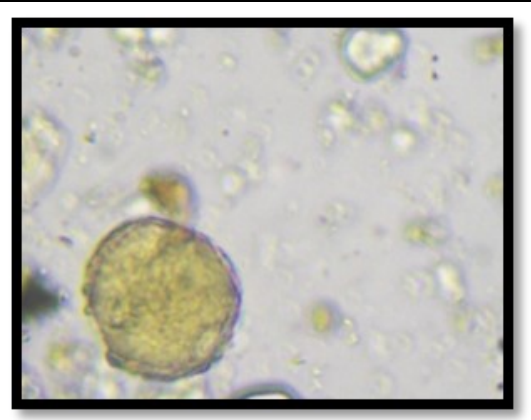

Pollen grains of Nagakeasra 


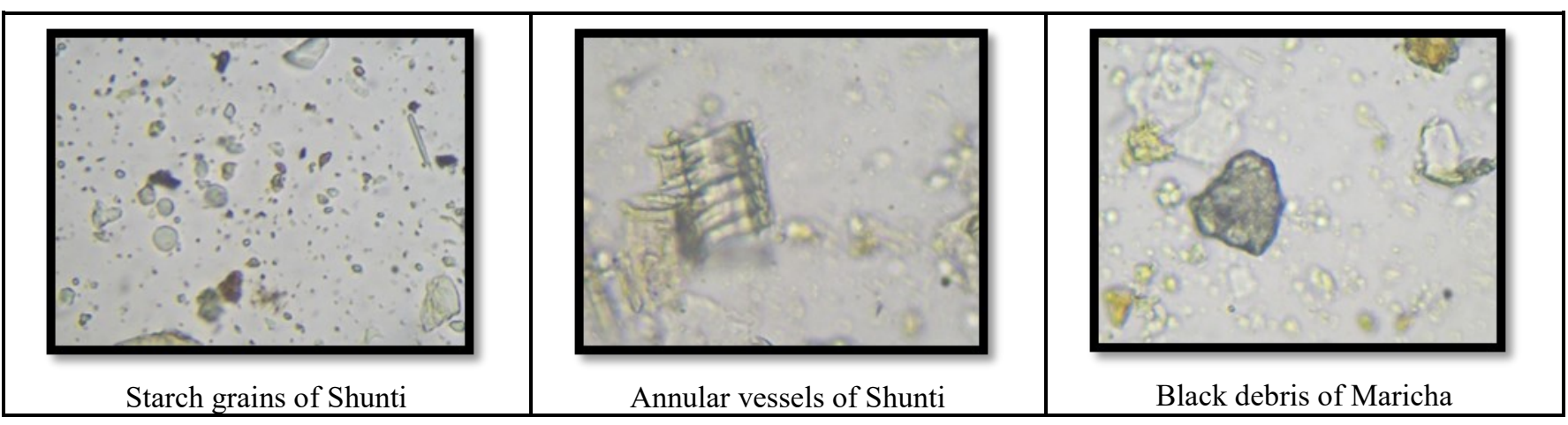

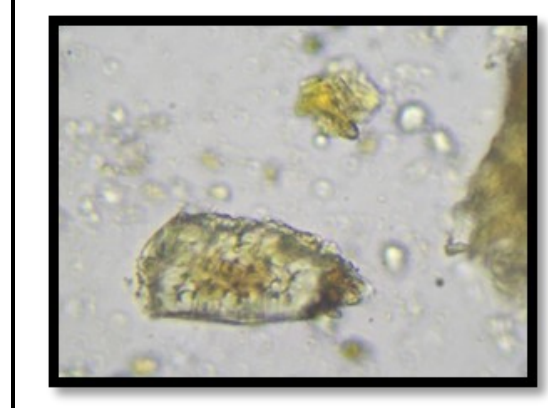

Stone cells of Maricha

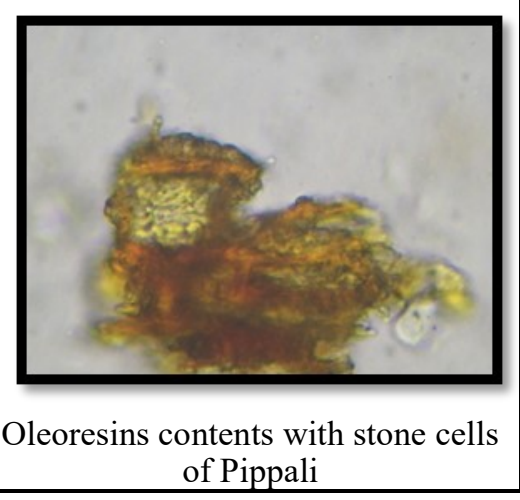

of Pippal

\section{Physico-Chemical Analysis}

Different parameters such as Loss on drying, $\mathrm{pH}$ Value, Water soluble extractive, Alcohol soluble extractive etc. were analyzed for different physico-chemical parameters and results are depicted in the table no.3:

Table 3. Physico-Chemical Parameters of Musta-Triphaladi Avaleha

\begin{tabular}{|l|l|l|}
\hline No. & Parameters & Musta-Triphaladi Avaleha \\
\hline $\mathbf{1 .}$ & Loss on drying at $110^{\circ} \mathrm{C}$ & $11.094 \% \mathrm{w} / \mathrm{W}$ \\
\hline $\mathbf{2 .}$ & pH Value & 6.0 \\
\hline $\mathbf{3 .}$ & Water soluble extractive & $76.29 \% \mathrm{w} / \mathrm{w}$ \\
\hline $\mathbf{4 .}$ & Alcohol soluble extractive & $83.65 \% \mathrm{w} / \mathrm{w}$ \\
\hline $\mathbf{5 .}$ & Ash Value & $0.142 \mathrm{~g}$ \\
\hline $\mathbf{6 .}$ & Acid insoluble Ash & $0.193 \%$ \\
\hline
\end{tabular}

\section{Discussion}

The therapeutic effect depends on the quality of the drug administered. To obtain the expected outcome after administration on particular disease, especially a combined drug formula all ingredients should be present in it. Pharmacognostical characteristic of MustaTriphaladi Avaleha under the microscope showed characters of all the ingredients of finished product, thus the study proves the quality of the final product. Priliminary physicochemical parameters also are with in the standared range.

\section{Conclusion}

Preliminary organoleptic characteristics and microscopic study of the Musta-triphaladi Avaleha showed that all ingredients used were genuine and all were found in the finished product too. Hence quality of Musta-triphaladi Avaleha is established in the given standard conditions and this study outcome may be cosidered as reference standard in furture scientific studies.

\section{References}

1) Shailesh R. Rajgolkar. A clinical study on Beejadushtijanya Pandu (Thalassemia Major) in children and its management with MustaTriphaladi Avaleha. Dept of Kaumarbhritya, IPGT \& RA, GAU, Jamnagar; 2011- 2014.

2) http://www.who.int/genomics/public/ geneticdiseases/en/index2.html [Assessed on 12.03.2016, $11.00 \mathrm{am}]$ 
3) Vinod K Paul, Bagga Arvind. Ghai Essential Paediatrics. 8ed. New Delhi; CBS Publishers \& Distributors Pvt Ltd; 2013. 341p.

4) Vinod K Paul, Bagga Arvind. Ghai Essential Paediatrics. 8ed. New Delhi; CBS Publishers \& Distributors Pvt Ltd; 2013. 342p.
5) Vinod K Paul, Bagga Arvind. Ghai Essential Paediatrics. 8ed. New Delhi; CBS Publishers \& Distributors Pvt Ltd; 2013. 343p.

6) Anonymous. The Ayurvedic Pharmacopeia of India. 1ed. Part 1. New Delhi; Govt. of India; 2006. volume 1. 7,8,33,62 p.

7) Anonymous. The Ayurvedic Pharmacopeia of India. 1ed. Part 1. New Delhi; Govt. of India; 2006. volume 2. $131 \mathrm{p}$.

$* * * * *$ 